\title{
Production of cytokinin-like substances and ethylene by the ectomycorrhizal fungus Cantharellus cibarius
}

\author{
EDMUND STRZELCZYK*, MARIA KAMPERT*, \\ ROMAN PACHLEWSKI ${ }^{\text {** }}$
}

'Department of Microbiology. Institute of Biology and Environment Protection

Nicolaus Copernicus University, Gagarina 9, 87-100 Toruñ. Poland

${ }^{* *}$ Forest Rescarch Institute, Sękocin, 05-550 Raszyn, Poland

Strzelezyk E. Ka mpert. M. Pa chlewski R. Prodaction of cytakinin-like substances and ethylene by the ectomycorrhizal fungus Cantharellus cibarius. Acta Mycol. 32 (1): 5-12. 1997.

It was found that the hardwood form of Canthareltus cibarius (strain 5400) produced less cytokinin-like substances than the coniferous form (strain 5410). Among the active substances the following were detected: 2iP, 2iP riboside and zeatin. No significant differences in ethylene production between both strains in the presence or absence of methionine (considered to be the precursor of this gas) were noted.

Key words: Cantharellus cibarius, ectomycorrhizal fungus, cytokinin-like substances, ethylene.

\section{INTRODUCTION}

There exists firm evidence thast plant growth regulators, among them cytokinins and ethylene produced by plants, are essential for their growth and development. Plant growth regulators are also produced by various microorganisms living in association with plants ( $\mathrm{G}$ o g a 1 a 1991). There is also evidence that plant growth hormones produced by bacteria can increase growth rates and improve yields of the host plant (B a r e a, B r o w n 1974). Different microorganisms both saprotrophic and pathogenic have been found to produce cytokinins ( $\mathrm{P}$ h ill i p s, T o r r e y 1972; K a m p e r t, S t r z e lczy k 1980; Strzelczy k, Kam pert 1983; Evidente et al. 1991).

Plant growth hormones affect not only the growth and development of the plant but they are also of importance in establishing and functioning of 
mycorrhizae (S I a n k is 1973; C r a f ts, M ille r 1973). Among the plant growth regulators cytokinins are of special interest. They stimulate cell division, modify cell enlargement, delay senescence, inhibit root elongation and protect the plant against pathogens by increasing the synthesis of phenolic compounds (D e k h u j z e n 1976). Therefore, it is not surprising that among plant growth regulators auxins and cytokinins are being considered of utmost importance in plant mycorrhizal fungus interrelationships. Cytokinins may modify the growth of cortical cells in such a manner as to facilitate the invasion of the root by the fungus. They also cause mobilization of nutrients to the region of mycorrhizal association $(\mathrm{Cr}$ a f ts, $\mathrm{M} \mathrm{iller}$ 1974).

Ethylene is an endogenous growth regulator that is produced by higher plants as well as by microorganisms. This gas affects plant growth and some of the biochemical processes in plants. Fungi are known to produce ethylene often in correlation with infection or pathogenesis (A r s c h e r, H is l o p 1975; G r a h a m, L in derm a n 1980).

Cantharellus cibarius is an ectomycorrhizal fungus of many forest trees ( $\mathrm{T} \mathrm{r}$ a p p e 1986). It is also an appreciated edible mushroom of significant economical importance. Yet because of many reasons this species was not intensively studied (D a n e 11 1994). To our knowledge papers published on this fungus are not numerous. Only one paper on $C$. cibarius has been published in Poland ( $\mathrm{Pachlewski}, \mathrm{Strzelczyk}, \mathrm{Kermen}$ 1996). Because no data on the production of plant growth regulators by this fungus are available, the synthesis of cytokinin-like substances and ethylene in two strains of $C$. cibarius was carried out.

\section{MATERIALS AND METHODS}

Origin of the is olates. Two isolates of the ectomycorrhizal fungus C. cibarius hardwood (strain No 5400) and coniferous (strain No 5410) strains were studied. Pure cultures were obtained from fruit bodies of this fungus growing under oak (No 5400) and pine (No 5410) as described in detail by Pachlewski, Strze lczyk and Kermen (1996).

$\mathrm{Cu} / \mathrm{tur}$ e $\mathrm{conditions}$. Both strains were cultured and stored on potato dextrose agar (Difco) slants. In this study they were grown in Lamb's (1974) medium-glucose $10 \mathrm{~g}, \mathrm{NH}_{4} \mathrm{Cl} 500 \mathrm{~g}, \mathrm{MgSO}_{4}, 7 \mathrm{H}_{2} \mathrm{O} 50 \mathrm{mg}, \mathrm{k}_{2} \mathrm{HPO}_{4}$ $50 \mathrm{mg}$, Na EDTA $1 \mathrm{ml} / 1$ of $5 \mathrm{ppm}$ Fe solution, thiamine $1 \mathrm{mg}$, biotin $0,01 \mathrm{mg}$. distilled water $1000 \mathrm{ml}$, pH 5,8-6,0. Erlenmeyer flasks ( $500 \mathrm{ml}$ ) containing $200 \mathrm{ml}$ of the above medium were inoculated with two discs ( $1 \mathrm{~cm}$ in diameter) cut from a 7 day-old agar (potato dextrose agar, Difco-PD) cultures of the fungi. 
The inoculated flasks were incubated at $26^{\circ} \mathrm{C}$ for 14 days. Subsequently the mycelium was separated from the medium by filtration on filter paper and dried at $85^{\circ} \mathrm{C}$ to constant weight. The experiments were set in quintuplicate.

E x t r a c t i o $\mathrm{n}$ of cytokinin-like substances (CLS). The supernatants were adjusted to $\mathrm{pH} 2.5-3.0$ with $1 \mathrm{~N} \mathrm{HCl}$ and passed through a Dowex $50 \mathrm{~W} \times 8$ (Merck) cation exchange column $\mathrm{H}^{+}$form, 50-100 mesh. The column was washed with $500 \mathrm{ml}$ of double distilled water and CLS were eluated with $340 \mathrm{ml}$ of $2 \mathrm{~N} \mathrm{NH}_{4} \mathrm{OH}$ followed by $680 \mathrm{ml}$ of $5 \mathrm{~N} \mathrm{NH}_{4} \mathrm{OH}$. The combined eluates were evaporated to dryness in vacuo at $80-85^{\circ} \mathrm{C}$ to remove ammonia. The dry residue (from $1000 \mathrm{ml}$ ) of culture fluid was dissolved in $2 \mathrm{ml}$ of $35 \%$ ethanol and applied to Sephadex LH-20 (Pharmacia, Uppsala) column $90 \times 25 \mathrm{~cm}$ and eluated with $35 \%$ ethanol. Four fractions, $10 \mathrm{ml}$ each, were collected and evaporated to dryness at $85^{\circ} \mathrm{C}$.

$\mathrm{B}$ i o s s a y (in triplicate) was performed using soybean callus according to $\mathrm{M}$ i u r a and M i 11 e r (1969). Three pieces of soybean - Glycina max (L.) Merill var. acme callus c 45-50 mg each were placed in each flask. The cultures were grown in an illuminated chamber at continuous illumination of 50 lux at $28^{\circ} \mathrm{C}$ for 25 days. The total amount of CLS produced was calculated from a standard response curve prepared for pure kinetin (Serva) and expressed as equivalents of kinetin (E.kin $\mu \mathrm{g} / \mathrm{g}$ dry weight of mycelium).

G a s c hromatography. This method was employed for more accurate identification of the cytokinin-like substances. For this purpose gas chromatograph Shimadzu GC-14 A was used. The samples (ethanol extracts) were dried at $\mathrm{N}_{2}$ and silylated with BSA (N,O-bis(trimethylsilyl)acetamide) and kept for $1 \mathrm{hr}$ at $80-85^{\circ} \mathrm{C}$. Samples $(1 \mu \mathrm{l})$ were injected onto a capillary column SE-54-DF-0,50 (25 $\mathrm{m} \times 0,32 \mathrm{ID})$. The carrier gas was $\mathrm{N}_{2}$ at a flow rate of $4 \mathrm{~cm}^{3} / \mathrm{min}$. The following cytokinin-like substances were used as standards: $2 \mathrm{iP}$ - $(6(\gamma, \gamma$-dimethylallylamino $)$ purine, R2iP - $(6(\gamma, \gamma$-dimethylallylamino $)$ purine riboside, zeatin riboside $(Z R)$ and zeatin $(Z)$. The conditions of the experimetn were as follows:

2iP - temperature column $200^{\circ} \mathrm{C}$, temperature of detector and injector $260^{\circ} \mathrm{C}, 2 \mathrm{iPR}-$ temperature column $260^{\circ} \mathrm{C}$, temperature of detector and injector $280^{\circ} \mathrm{C}, \mathrm{ZR}$ - temperature column $280^{\circ} \mathrm{C}$, temperature of detector and injector $320^{\circ} \mathrm{C} ; \mathrm{Z}$ - temperature column $230^{\circ} \mathrm{C}$, temperture of detector and injector $280^{\circ} \mathrm{C}$.

E thy 1 e ne de te ct i o n. The fungi were cultured in sterile bottles with rubber stoppers. Some of them received $400 \mathrm{mg} / 1$ of methionine filter sterilized (millipore $0,45 \mu \mathrm{m}$ ) as the precursor of ethylene. Each $100 \mathrm{ml}$ bottle containing $50 \mathrm{ml}$ of liquid Lamb's medium was inoculated with one disc $(1 \mathrm{~cm})$ cut from a PD culture. The cultures were grown for 14 days at $26^{\circ} \mathrm{C}$. 
After 14 days of growth $1 \mathrm{ml}$ ethylene-in-air were withdrawn from the flasks and analysed by gas chromatograph Shimadzu GC-14 A with Porapak $\mathrm{P}$ column $2 \mathrm{~m} \times 1,8(80-100 \mathrm{mesh})$. The conditions of the experiment were as follows: temperature of the column $100^{\circ} \mathrm{C}$, temperature of the detector and injector $120^{\circ} \mathrm{C}$. Subsequently the mycelium was separated from the medium by filtration on filter paper and dry mass was determined after drying to constant weight at $85^{\circ} \mathrm{C}$. Data were evaluated statistically using the following methods: 2 -factors ANOVA comparing the effects of methionine (2) and strain (1) on ethylene production and the Newman-Keuls multiple range test (comparison of averages $\mathrm{p} \leqslant 0,05$ ).

\section{RESULTS}

It was found that $C$. cibarius strain 5400 produced less CLS than strain 5410 per gram of dry mycelium. However, the differences were not statistically significant. Thus it may be assumed that both strains produced in fact the same amount of these substances (Table 1). The largest increase of soybean callus caused by the medium of the strain 5410 was noted in fraction numbers 16-20 which correspond to 2iP and 2iP riboside and in fraction 36-40 which corresponds to zeatin when compared with the standards (Fig. 1). The 2iP and zeatin were synthesized only by the coniferous form 5410 as shown by gas chromatography (Fig. 2). No cytokinin-like substances were found in the strain 5400 when gas chrmatolography was used. Both strains of $C$. cibarius produced ethylene. However no effect of methionine, which is assummed to be the precursor of this gas, in both strains was noted (Table 2).

Table 1

Production of cytokinin-like substances by Cantharellus cibaritus

\begin{tabular}{|c|c|c|c|}
\hline \multirow{2}{*}{ Strain number } & \multicolumn{2}{|c|}{ Quantity of CLS (in equivalents of kinetin) } & \multirow{2}{*}{ Fraction No } \\
\cline { 2 - 3 } & $\mu \mathrm{g} / \mathrm{ml}$ medium & $\mu \mathrm{g} / \mathrm{g}$ dry mass & \\
\hline 5400 & 0.0060 & 0.0132 & $16-32$ \\
5410 & 0.0048 & 0.0169 & $16-24 ; 40$ \\
\hline
\end{tabular}

Ta ble 2

Production of ethylene by Cantharellus cibarius

\begin{tabular}{|c|c|c|}
\hline \multirow{2}{*}{ Strain number } & \multicolumn{2}{|c|}{ Quantity of ethylene in $\mathrm{nM} / \mathrm{g}$ dry mass $\pm \mathrm{S} . \mathrm{E}}$. \\
\cline { 2 - 3 } & without methionine & with methionine \\
\hline 5400 & $12186.72 \pm 7571.72$ & $7827.51 \pm 5789.44$ \\
5410 & $3575.03 \pm 395.98$ & $6079.43 \pm 2078.91$ \\
\hline
\end{tabular}




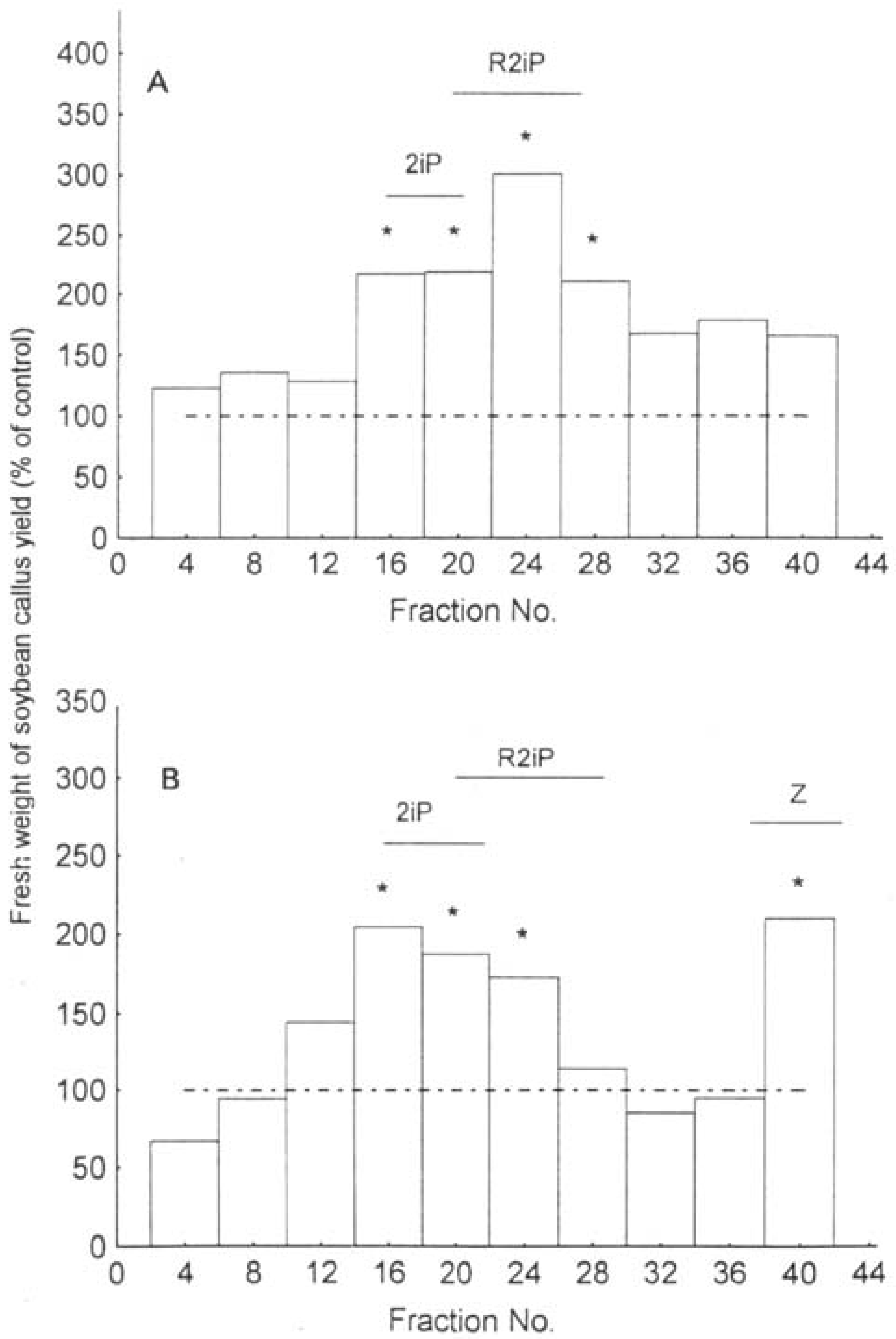

Fig 1. Column chromatographic analysis of CLS produced by Cantharellas cibarius 5400 (biotest soybean callus)

Horizontal dashed line - control 100\%: $(\mathrm{n}=3) \mathrm{p} \leqslant 0.05]: 2 i \mathrm{P}-6(\gamma, \gamma$-dimethylallylamino $)$ purine; $\mathrm{R} 2 \mathrm{iP}-6(\gamma, \gamma$-dimethylallylamino $)$ purine riboside; $\mathrm{Z}$ - zeatin 


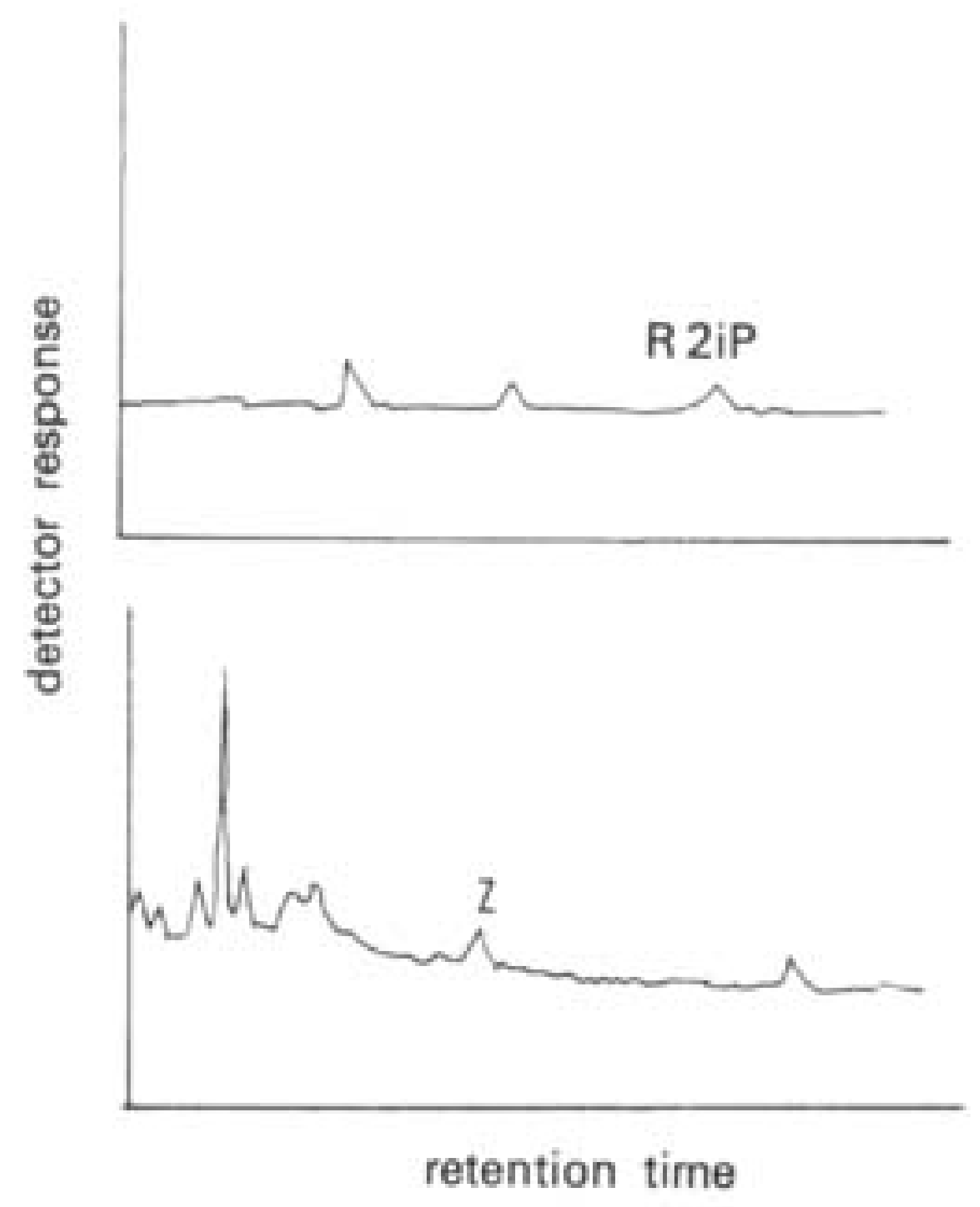

Fig. 2. Gas chromatographic analysis of CLS produced by Cantharellus cibarius 5410 R2iP $-6(\gamma, \gamma$-dimethylallylamino) purine riboside; Z - zeatin

\section{DISCUSSION AND CONCLUSIONS}

Among the numerous possible effects that soil microorganisms may exert on plants is the production of plant growth regulators ( $\mathrm{K} \mathrm{a} \mathrm{tz \textrm {nel }} \mathrm{s}$ o $\mathrm{n}$ 1965; G a r b a y e 1991; G o g a I a 1991). Because of intensive development of microorganisms in the root zone it might be expected that the greatest amount of these substances would be produced therein by them ( $\mathrm{K} \mathrm{a} \mathrm{t} \mathrm{z} \mathrm{-}$ n e Is o n 1965). Among the metabolites affecting mycorrhiza formation and functioning plant growth regulators are being considered of importance (H o r a k 1965; S I a n k i s 1973; G o g a l a 1991). Auxins and cytokinins were most often studied (K a m pert, S trze l c z y k 1980; S trze lc z y k, K a m p e r t 1983; S t r z e l c z y k at al. 1989) as they are thought to be of the utmost importance in plant mycorrhiza relationships. On the other hand data on the production of ethylene, especially by mycorrhizal fungi, are scarce and have been investigated only recently ( $G$ o g a l a 1991). However it is assumed that ethylene in addition to auxins and cytokinins plays an important role in mycorrhiza formation and functioning ( $\mathrm{S}$ I a $\mathrm{n} \mathrm{k}$ is 1973). $\mathrm{S} \mathrm{m} \mathrm{it} \mathrm{h} \mathrm{and} \mathrm{Restall} \mathrm{(1971)} \mathrm{indicated} \mathrm{that} \mathrm{ethylene} \mathrm{was} \mathrm{normally}$ produced under anaerobic conditions. However, it was found that the importance of such conditions depends upon the provision of substrates. When glucose and methionine (which is supposed to be a precursor in ethylene 
production) are provided, the production of ethylene by Mucor hiemalis and by soil is stimulated (Lynch, Harper 1974). No significant differences in ethylene production between both strains studied in our work (with and without methionine) were found. Also cytokinins were synthesized by both forms of Cantharellus cibarius.

Fungi form the largest and probably the most important portion of the microbial population of forest soils. Yet most research on these organisms concerned ecological and taxonomical rather than physiological studies (Manka, Truszkowska 1958; Kowalski 1974). Therefore the objective of this work was to study the production of cytokinin-like substances and ethylene by the important and poorly studied fungal species Cantharellus cibarius. Such studies are certainly of biological and ecological importance. However we are aware of the danger of extrapolation from studies in vitro. Nevertheless it seem that it is essential to isolate organisms in order to determine their physiological, biochemical and other activities and to find out what they are capable of doing under controlled conditions. Earlier studies and the present data indicate that the production of plant growth regulators is quite common among symbiotic and non-symbiotic soil microorganisms (Strzelczyk et al. 1989). The plant growth regulators studied were produced by both strains of $C$. cibarius.

\section{REFERENCES}

Archer S. A. Hislop E. C. 1975. Ethylene in host-pathogen relationship. Ann. Appl. Biol. 81: $121=126$.

Barea J., Brown M. E. 1974. Effect of plant growth produced by Azorobacter paspali related to synthesis of plant growth regulating substances. J. Appl. Bacteriol. 37: 4-10.

Crafts C. B, and Miller C. O. 1974. Detection and identification of cytokinin produced by mycorrhizal fungi. Plant Physiol. 54: 586-588.

Danell E. 1994. Formation and growth of the ectomycorrhiza of Cantharellus cibarius. Mycorrhiza 5: 89-97.

Dekhuijzen H. M. 1976. Endogenous cytokinins in healthy and disceased plants. [In]: Encyclopedia of Plant Physiology 4: 526-559. Berlin.

Evidente A. Fuij T, Iacobellis N. S, Riva $S_{\text {, }}$ Sisto A., Surico G. 1991. Structure activity relationships of zeatin cytokinins produced by plant pathogenic Pseudononas. Phytochemistry 30: 3505-3510.

Garbaye J. 1991. Biological interactions in the rhizosphere. Experientia 47: 370-375.

Gogala N. 1991. Regulation of mycorrhizal infection by hormonal factors produced by hosts and fungi. Experientia $47: 331-340$.

Graham J. H., Linderman R. G. 1980. Ethylene production by ectomycorrhizal fungi Fusarium oxysporum f. sp. pini and aspetically synthesized ectomycorrhizae and Fusarium infected Douglas-fir roots. Can. J. Microbiol. 26: 1340-1347.

Horak E. 1960: Untersuchungen zur Wuchsstoffsynthese der Mycorrhizapilze. Intern. Symp., Weimar VEB, Jena. 
$\mathrm{K}$ a mpert M. Strzelezy k E. 1980: The synthesis of cytokinin-like substances by Coryneform - bacteria isolated from the the roots of pine seedlings (Pinus sy/vestris L.) Acta Microbiol. Polon. 29: 117-124.

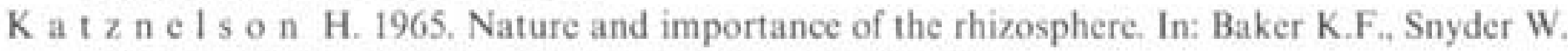
(Eds,): 187-209. California Press, Berkeley, Los Angles.

$\mathrm{K}$ ow a I s k i S. 1974. Groups of forest fungi in soil environment of selected pine cultures (In Polish). PTPN. Prace Kom. Nauk Roln. Leśn. 38: 123-128.

$\mathrm{L}$ a $\mathrm{m}$ b R. J. 1974. Effect of D-glucose on utilization of single carbon source by mycorrhizal fungi. Trans: Brit. Mycol. Soc. 62(2): 295-306.

L y $\mathrm{nch}$ J. M. Ha r per S. H. T. 1974. Formation of ethylene by soil fungus, J. Gen. Microbiol. 80: 187-195.

M a $\mathrm{n} k$ a K. T $\mathrm{r} u s z \mathrm{k}$ o w s k a W. 1958. Proba mykologicznej analizy korzeni swierka (Picea exce/sa L.). Acta Soc. Bot. Pol. 27. 1: 45.

$\mathrm{M}$ i u f a G. A., M ille r C. O. 1969. Cytokinins from a variant strain of cultured soybean callus, Plant Physiol. 44: 1035-1038.

Pachlewski R., Strzelezyk E, Kermen J. 1996. Studies of Camtharellus cibarius a mycorrhizal fungus of pine and spruce. Acta Mycol. 31 (2): 143-150.

Phillips D. A. Tor e y J. G. 1971. Studies on cytokinins production by Rhizobim. Plant Physiol. 49: 11-15.

S I a $\mathrm{n} \mathrm{k}$ is V. 1973. Hormonal relationships in mycorrhizal development. In: Marks G.C., Kozlowski T. (Eds,). Ectomycorrhizac - Their Ecology and Physiology: 231-298. Acad. Press, New York.

$\mathrm{S} \mathrm{m}$ it h K. A., Res $\mathrm{t}$ a II S. W. F. 1971. The occurrence of ethylene in anacrobic soil. Soil Sci. $22 ; 430-431$.

Strzelezyk E. Ka m pert M. 1983. Production of cytokinin-like substances by Cylindrocarpon destructams (Zins.) Scholt isolates pathogenic and non-pathogenie to fir (Abies aba) seedlings. Phytopathol. Z. 106: 90-96.

Strzelezyk E, Pokojska A Kampert M, Michalski L. Kowals $\mathrm{k}$ i S. 1989. Production of plant growth regulators by non-mycorthizal fungi associated with the roots of forest trees. In Interrelationships between microorganisms and plants in soil. (Eds. Vancura V. Kunc F., Publ. House Crechoslov. Acad. Sei. Praha, 213-222.

Trappe J. M. 1962. Fungus associates of ectotrophic mycorrhizac. Bot. Rev. 28: 538-606.

\title{
Wytwarzanie substancji typu cytokininy oraz etylenu przez ektomikoryzowy grzyb Cantharellus cibarius
}

\author{
Streszezenie
}

Stwierdzono, ze Cantharellus cibarius pochodzacy z lasu lisciastego wytwarzal mnicj substancji typu cytokininy anizeli zebrany w lesie iglastym. Wśród aktywnych substancji wykryto $2 \mathrm{iP}$, 2iP hydrazyd i zeatynç. Stwierdzono nieznaczną róznice w wytwarzaniu etylenu w obecności metioniny (uwazanej ze prekursora tego gazu) przez obydwa szcrepy. 